\title{
The Harvard Undergraduate Library Of 1773
}

By JOE W. KRAUS

$\mathrm{K}^{\mathrm{B}}$

eYes D. Metcalf pointed out several

years ago that the undergraduate college library was not an invention of the twentieth century, ${ }^{1}$ and the recent publication of a 1661 letter of Rector Olf Rudbeck of the University of Uppsala ${ }^{2}$ suggests that Europeans may have had the audacity to try out the idea before we did. No one, however, has taken the trouble to take a close look at the book collection that was selected for Harvard undergraduate students of the late eighteenth century.

Harvard's most disastrous fire destroyed old Harvard Hall on January 26, 1764 , and with it a library estimated to contain five thousand volumes as well as the scientific apparatus of the college and the personal belongings of the students. Disaster was quickly turned to fortune. A new Harvard Hall arose, phoenix-like, on the ruins of the old building. ${ }^{3}$ Friends of the college responded magnificently to appeals for books and funds. ${ }^{4}$ And college authorities prepared to restore order and get the boys back to school. By December 1765, the president and fellows felt it necessary to draw up a revised set of regulations for the new library. ${ }^{5}$ These regulations have frequently been

1 "The Undergraduate and the Harvard Library, 1765-1877," Harvard Library Bulletin, I (1947), 29-51. President Three Hundred Years Ago" AAUP Bulletin, XLVI (1960), 381-382.

3 F. Foster Apthorp, "The Burning of Harvard Hall, 1764 and Its Consequences" Colonial Society of Mas-

sachusetts, Publications, XIV (1913), 2.43. (Boston: 1860) II, 485-496.

Louis Shores, Origins of the American College Library (Nashville, Tenn.: 1934), pp. 185-194; copied from Harvard College Book, No. 7. The rules as they were revised for the 1767 Laws of Harvard College are printed in Colonial Society of Massachusetts, Publications, XXXI, (1935),369-375.
Mr. Kraus is Librarian of Madison College, Harrisonburg, Va.

cited as examples of the severe restrictions that eighteenth-century colleges placed on the use of books, and by twentieth-century standards they do reflect an emphasis on custodianship that is inconsistent with present day college teaching. What is frequently over-looked, however, is the fact that these laws were considerably more liberal than preceding regulations. Specifically, the 1765 laws permitted junior as well as senior sophisters to borrow books from the library, increased the loan period from a month to six weeks, required the librarian to keep the library room open (and heated) each Wednesday morning and afternoon so that students might study the books which could not be borrowed, and enabled students to reserve books which had been borrowed by others.

Regulation number five went an important step farther in specifying that

There shall be a part of the Library kept distinct from the rest as a smaller Library for the more common use of the College. When there are two or more setts of Books, the best shall be deposited in the great Library \& the others in the great or small Library, at the discretion of the committee for placeing the Books. This committee shall also lay apart \& with the assistance of the Librarian prepare a catalogue of such Books, as they judge proper for the smaller Library.

The first printed catalog of this smaller library appeared in 1773 under the descriptive title Catalogus Librorum in Bib- 
liotheca Cantabrigiensi Selectus, Frequentiorem in Usum Harvardinatum, Qui Baccalaurei in Artibus Nondum Sunt Donati. Although the catalog contains only brief, and sometimes puzzling, entries it is possible to identify most of the authors and titles by referring to the 1790 Catalogus Bibliothecae Harvardianea Cantabrigiae Nov-Anglorum which contains full and remarkable accurate bibliographical details. We have no certain way of knowing how many books were in the larger library in 1773 but Ezra Stitles who visited the library at commencement in 1766 reported that there were 4,350 volumes in six alcoves. By 1790 the book collection was estimated to contain 12,000 volumes. ${ }^{6}$ If we can assume a constant rate of growth between these two dates, the 827 titles (about 1700 volumes) included in the 1773 catalog were selected from a larger collection of at least 6,600 volumes.

The foreword (Monitum) to the 1773 catalog states the limitations which the committee used in selecting the books to be included:

Inasmuch as the Catalogue of Books in the College Library is very long, and not to be completely unrolled when Occasion demands, save at very great expense of time, embracing Books in almost all Tongues and about all Sciences and Arts, most of which are above the comprehension of Younger Students, it has seemed wise to put together a briefer Catalogue, to wit, of Books which are better adapted to their use. In the following Catalogue, then, in addition to Classical Authors, there are included Books chiefly in the vernacular Tongue and belonging to the general culture of the mind, omitting those which are in daily use in the College, as also those which are written in foreign Languages, or which treat of specialized Disciplines, e.g., Medicine or Jurisprudence. But let no one infer from this that students are debarred from the freer use of the Library. ${ }^{7}$

${ }^{\circ}$ C. E. Wilton, "Harvard College Library, 1638 1938," Harvard Library Notes, III (1939), 257.

7 Quoted in Metcalf, "The Undergraduate and the Harvard Library, 1765-1877," Harvard Library Bulletin, I (1947), 30. The translation is by Arthur Stanley Pease.
Harvard's concept of "the general culture of the mind" in 1773 gave a prominent place to theology-but less prominent than in other college library catalogs published in the eighteenth century 8 - and included liberal proportions of history, literature, and science. Books pertaining to these four subjects made up nearly three-fourths of the titles in the catalog. The following table was compiled by classifying and counting the titles in the catalog rather than by working with the books themselves and the figures must be taken as approximations.

$\begin{array}{lcc}\text { Subject } & \text { No. of Titles } & \text { Percentage } \\ \text { Theology } & 246 & 30 \% \\ \text { History } & 154 & 19 \% \\ \text { Literature } & 126 & 15 \% \\ \text { Science } & 86 & 10 \% \\ \text { Biography } & 52 & 6 \% \\ \text { Geography } & 48 & 6 \% \\ \text { Philosophy } & 38 & 5 \% \\ \text { Government } & 25 & 3 \% \\ \text { Law } & 12 & 1 \% \\ \text { Arts } & 7 & \% \\ \text { Other Subjects } & 26 & 3 \% \\ \text { Unclassified } & 7 & 1 \% \\ & & 99 \%\end{array}$

${ }^{*}$ less than 1 per cent

Among works of theology the selections apparently were intended to provide books representing divergent points of view. The forty-four writers whose complete works were listed were about equally divided between Anglican and non-conforming divines. The Church of England writers included such familiar names as Richard Allestree, Isaac Barrow, William Sherlock, Archbishop Tillotson, and Bishops Bull, Burnet, Stillingfleet, Smalridge, and Hoadly, while the non-conforming writers included the

\footnotetext{
8 In the Yale Library Catalog of 1743, 46 per cent of the books pertained to theology. In other catalogs the the books pertained to theology. In other catalogs the percentages were as follows: Yale (1755), 45; College
of New Jersey $(1760), 46$; Harvard (1790), 49; Yale (1791), 54; College of Rhode Island (1793), 34. Joe W. Kraus, "The Book Collections of Five Colonial College Libraries; a Subject Analysis," unpublished Ph.D. dissertation, University of Illinois, 1960.
} 
Presbyterians Isaac Ambrose, Richard Baxter, William Bates, John Flavel, Joseph Boyse, and Thomas Manton and a variety of other independent ministers, such as Edmund Calamy, Philip Doddridge, Henry Grove, David Jennings, John Leland, John Owen, Isaac Watts, and Daniel Williams. Writers favorable to the Arminian position included George Benson and Phillippus van Limborch. The works of Archbishop Fénelon, in French, were the only volumes by a Roman Catholic writer, and they were opposed by Nathaniel Vincent's MorningExercise Against Popery and a translation, with a satirical dedication to Pope Innocent XI, of Sir Richard Steele's Account of the State of the Roman-Catholick Religion Throughout the World.

Although the range of opinions was great, most of the theological works were limited to books for laymen. Almost all of the books were in English, few dealt with technical problems of doctrine, and there were only six titles dealing with writers of the early Christian church. Books which sought to rationalize the conflict between science and religionWilliam Derham's Astro-Theology and Bernard Nieuwentijdt's Religious Philosopher, for example-and those which re-examined the nature of miracles and revelation against the inroads of eighteenth-century rationalism made up a sizable group. Translations of the Bible included modern English versions of the Psalms by James Merrick and of Job by Thomas Heath, the paraphrases of the Old and New Testaments by Thomas Pyle, and versions and paraphrases of the New Testament by Edward Harwood, John Worsley, and John Guyse, and James Macknight's Harmony of the Four Gospels. Thirty titles of Biblical commentaries and other aids to Bible study include the commentaries of Matthew Poole, Bishop Patrick, and Matthew Henry, but the great exegetical works, the polygot Bibles, and other learned treatises intended for ministers were not among them. Presumably the aspiring young preachers would find these works in the larger library.

The Library was strong in ancient history and the history of England and included some unexpected works on American history. Most of the books on ancient history, which made up about one-fourth of all the historical collection, were in English. Even five of the fifteen classical Greek and Roman historians were available in English translations. In English history there were several important compilations, among them, Abel Boyer's History of the Reign of Queen Anne (11 vols.), David Hume's History of England (6 vols.), Clarendon's History of the Rebellion (3 vols.), The Compleat History of England (3 vols.) completed by Bishop White Kennett, Tobias Smollett's History of England (15 vols.), Rapin-Thoyras' History of England translated and continued by Nicolas Tindal ( 5 vols.), and the Parliamentary or Constitutional History of England (24 vols.), and an interesting assortment of such earlier works as William Camden's Britannia and Thomas Hearne's Collection of Curious Discourses. There were five histories of France, two works on the history of Denmark and Sweden, single volumes on Holland, Spain, Hungary, Russia, Poland, and Geneva, and general histories of Europe by Pufendorf and by John Campbell. Histories of America were few although Thomas Hutchinson's History of Massachusetts Bay, Daniel Neal's History of the Puritans and his History of New-England, the six-volume General History of the Vast Continent and Islands of America by Herrear y Tordesillas, and Garcilaso de la Vega's Royal Commentaries of Peru were included along with histories of New York, California, and Greenland and with some political tracts. There were works on the reformation by Geeraert Brandt and Benjamin Bennet and general ecclesiastical histories by Louis Ellis Dupin, Laurence Eckard, and Johann Lorenz 
Mosheim and Paolo Sarpi's History of the Council of Trent, a book that appears in almost every library list of the seventeenth and eighteenth centuries. Jewish history was represented by Josephus' History with the continuation by Jacques Basnage, Claude Fleury's Les Moeurs des Israelites, Thomas Lewis' Origines Hebraeae, two works by Moses Lowman, and Adrianus Reeland's Antiquitates Sacrae Veterum Hebraeorum.

About half of the titles classified as literature were classical Greek and Latin writings but fourteen of the thirty-eight authors included were available in English translations. Almost all of the Greek writings were available in parallel Latin and Greek texts although all but six of the Latin authors could be read only in Latin. Students could read Callimachus, Pindar, Demosthenes, Hesiod, Homer's Odyssey, Sophocles, and Longinus without a knowledge of Greek and Cato, Cicero, Lucan, Pliny, Sallust, and Tacitus without Latin. English literature was well represented although some of the books on the shelves would seldom be found in undergraduate libraries today. The works of Shakespeare, Milton, Addison, Gay, Pope, Thomson, James Macpherson, Waller, and Spenser's Faerie Queene were there along with William Shenstone, Nicholas Rowe, Lord Roscommon, Mrs. Elizabeth Rowe, Christopher Pitt, John Philips, William Mason, Sir Samuel Garth, and George Lillo. Percy's Reliques of Ancient English Poetry and an edition of Dodsley's Poems added considerably to the shelf of English poetry and Horace Walpole's Catalogue of the Royal and Noble Authors of England, Scotland and Ireland provided a useful bio-bibliography. Other modern literature was limited to a few French and Italian authors: Boileau, La Rochefoucauld, a translation of Madame Sévigne's Letters to Her Daughter, Tasso's Gerusalemme Liberata in Italian and in English, the works of Francesco Algarotti and two Italian grammars.
Although works of science made up only 10 per cent of all titles among the books set aside for undergraduate reading, the importance of the books selected is greater than the proportion would indicate. There was a substantial portion of the Descriptions des Arts et Metiers of the Academie des Sciences of Paris (100 vols.), all of the volumes of the Commentarii Academiae Scientiarum Imperialis Petropolitanae of the Leningrad Academy and part of the Novii Commentarii of the same Academy, and four volumes of the Götingische Gelehrte Anziegen. The Philosophical Transactions of the Royal Society of London were available in John Lowthorp's abridgement, and the histories of the Society by Thomas Sprat and by Thomas Birch were included. Other general works of science included the works of Robert Boyle, all the works of Benjamin Martin, and John Harris' Lexicon Technicum.

Newton's influence was dominant in the collection. Not only were there Latin and English editions of his works but expositions of Newton by Henry Pamberton, John Mason, and Colin Maclaurin were also available. Other important eighteenth-century mathematicians whose works were included were Brook Taylor and Thomas Simpson. Jacques Ozanam's four-volume Cursus Mathematicus was a useful survey for students, and a history of the subject was provided by Jean Étienne Montucla's Histoire des Mathématiques, Edmund Halley's edition of the Conic Sections of Apollonius of Perga and a Greek and Latin text of the Sphaerica of Theodosius of Tripolis. An equally good sampling of eighteenthcentury writings on physics included writers from several countries: Franz Ulrich Theodor Æpinus and Petrus van Musschenbroek from Holland; Jean Antoine Nollet from France; the SerboCroat Rudjer Josip Boškovic; Joseph Priestley, John Theophilus Desaguliers, and John Keill from England, and Frank- 
lin from America. John Clarke's translation of Jacques Rohault's Physica with Samuel Clarke's notes provided a bridge from Cartesian to Newtonian theories. Sixteen volumes of the works of Carl von 'Linne-the precise titles are not given-and "all the works" of John Ray were in the science collection, but the remaining books of biology were less important works, such as Richard Bradley's Philosophical Account of the Works of Nature and a translation of Noel Antoine Pluche's Spectacle de la Nature. Astronomy had apparently become a less important subject for undergraduate reading than mathematics and physics, for in addition to Edmond Halley's $A s$ tronomical Tables and two reports from French royal scientific expeditions, Maupertuis' Figure de la Terre and La Condamine's Journal du Voyage . . . a l'Équateur there were only a half-dozen elementary works on astronomy. Despite the intention, expressed in the preface to the catalog, of excluding works on medicine, five titles by Herman Boerhaave, three by Richard Mead, and two by John Arbuthnot were listed along with an edition of Hippocrates, William Cheselden's Anatomy, and three other works.

There was an interesting collection of biographical works, a collection about equally divided between lives of theologians and of historical and literary personages, with some important biographical compilations. Lives of Archbishop Laud, Philip Doddridge, Bishop Kennett, Matthew Henry, Cardinal Wolsey, Archbishop Tillotson, and Benjamin Colman were included along with biographies of Henry VIII, Queen Elizabeth I, James I, Charles I, Charles II, Oliver Cromwell, Alexander Pope, Cicero, Charles V, Gustavson Eriksson of Sweden, and accounts of the trials of John Hampton and of Henry Sacheverell. Anthony à Wood's Athenae Oxonienses, John Campbell's Lives of the Admirals and Other Eminent British Seamen, John
Ward's Lives of the Professors of Gresham College, Basil Kennett's Lives and Characters of the Ancient Grecian Poets, Lewis Crusius' Lives of the Roman Poets, and the Biographia Britannica were among the collective biographies recommended for undergraduate students.

The collections of voyages by Awnsham Churchill, John Harris, and William Dampier were supplemented by travelers' accounts of a good many parts of the world, with some emphasis on the lesser-known areas, with five books on the Levant, three descriptions of the Holy Land, Alexander Hamilton's New Account of the East Indies, Boswell's Account of Corsica, John Byron's Narrative and accounts of Sicily, Abyssinia, China, Spain and Portugal, Ceylon, Denmark, Italy, Russia, and Switzerland. The American continent was described in eight works including the travel accounts of Louis Hennepin and Louis Armand de Lom d'Arce, baron of Lahontan, Antonio de Ulloa's Voyage to South America, and Arthur Dobbs' Account of the Countries Adjoining to Hudson's Bay. Two collections of Jesuit letters from foreign missions-one in English and one in French-were an unexpected addition to the geographical books.

The emphasis of the books of philosophy was clearly on the eighteenth-century thinkers: John Locke, Bishop Berkeley, Thomas Reid, Adam Smith, and Francis Hutcheson were among the more prominent names included in the catalog. The works of Francis Bacon and Ralph Cudworth's True Intellectural System of the Universe were the notable representatives of the seventeenth century. The ancient philosophers were not neglected, however. Aristotle, Plato, Epictetus, Aeschines, Socrates, Theophrastus, and the compendium of Diogenes Laertius were available in Greek or Latin as well as translations of the Meditations of Aurelius Antoninus and Thomas Stanley's History of Phi- 
losophy. Formal systems of logic and the writings of the scholastic philosophers which were important parts of earlier college libraries had now given way to such books as James Burgh's Dignity of Human Nature, William Hogarth's Analysis of Beauty, Edmund Burke's Philosophical Enquiry into the Origin of Our Idea of the Sublime and Beautiful, Adam Smith's Theory of Moral Sentiments, and John Beattie's Essay on the Nature and Immutability of Truth.

A score of books on government were concerned with political theory rather than with the administration of local government. James Harrington's Commonwealth of Oceana, Algernon Sidney's Discourses Concerning Government, the works of Montesquieu (in French), Thomas Pownall's Principles of Polity and his Administration of the Colonies, and works on the English constitution by James Tyrrell, Gilbert Stuart, and Edward King were among the more noteworthy titles included. Fourteen works on law were included despite the statement in the preface to the catalog that such specialized disciplines were to be omitted. The works of Blackstone, Grotius' De Jure Belli et Pacis and Thomas Rutherford's Cambridge lectures on this work, Vattel's Law of $\mathrm{Na}$ tions and Pufendorf's work bearing the same title, a translation of Jean Jacques Burlamaqui's Principes du Droit Naturel and Cesare Beccaria's Dei delitti $e$ delle pene were available. An edition of Justinian's Institutions and Richard Burn's treatise were the only works on ecclesiastical law.

Among the remaining publications were a select group of magazines, including the Spectator, the Idler, the Rambler, the Tatler, the World, the Preceptor, Sir Richard Steele's Englishman, the Gentleman's Magazine and the London Maga- zine, seven volumes of the Annual Register, twenty-five volumes of the Historical Register, and thirty-three volumes of a publication-probably the Memoriesof the Academie des Inscriptions et Belles Lettres of Paris. Works on education by Joseph Priestley and Thomas Sheridan and guides to study by John Clarke, William Smith, and John Boswell were available, and for accounts of the British universities there were Edmund Miller's Account of the University of Cambridge and John Ayliffe's Ancient and Present State of Oxford. Three works on painting, the most important of which was Horace Walpole's Anecdotes of Painting in England, were the only books pertaining to the fine arts, William Lewis' Commercium Philosophico-Technicum; or The Philosophical Commerce of Arts the only work concerned with trade and commerce, and Ephraim Chambers' Cyclopaedia and an English version of Boyle's Dictionaire Historique et Critique the only general reference works.

By 1773 not only had the Harvard Library recovered the losses caused by the fire of 1764 but college authorities had relaxed the regulations governing the use of the library and had established a separate collection for undergraduate students. This collection of some eight hundred titles, selected by a committee of the faculty, provides evidence of the importance given to the library by college teachers and a clue to the subjects and the books that were considered important in the education of this generation of college students. The Catalogus Librorum in Bibliotheca Cantabrigiensi Selectus, Frequentiorem in Usum Harvardinatum, Qui Baccalaurei in Artibus Nondum Sunt Donati is a document of considerable importance in the educational history of the latter part of the eighteenth century. 